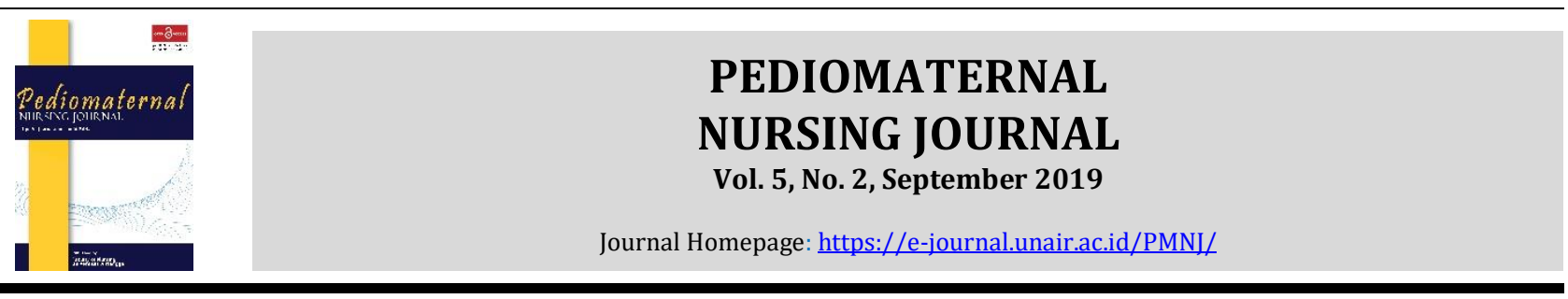

Original Research

\title{
Faktor Risiko Dropout Kontrasepsi Suntik Progesteron
}

\section{(The Risk Factor of Progestogen-only Injectable Contraceptive Discontinuation)}

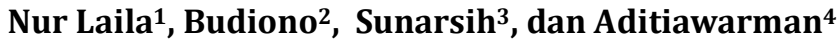 \\ ${ }^{1}$ Program Studi Kebidanan, Fakultas Kedokteran, Universitas Airlangga, Surabaya, East Java, Indonesia \\ ${ }^{2}$ Departemen IKM-KP, Fakultas Kedokteran, Universitas Airlangga, Surabaya, East Java, Indonesia \\ ${ }^{3}$ Politeknik Kesehatan Kementerian Kesehatan Surabaya, East Java, Indonesia \\ ${ }^{4}$ Divisi Fetomaternal SMF Departemen Obstetri dan Ginekologi RSUD Dr. Soetomo, Surabaya, East Java, Indonesia
}

\section{ARTICLE HISTORY \\ Received: June 3, 2019 \\ Accepted: Oct 21, 2019 \\ KEYWORDS \\ progestogen-only injectable discontinuation; desire pregnancy; myths; side effects; husband support}

\section{CORRESPONDING AUTHOR}

Nur Laila nur.laila-2015@fk.unair.ac.id Program Studi Kebidanan, Fakultas Kedokteran, Universitas Airlangga, Surabaya, East Java, Indonesia

Cite this as:

\begin{abstract}
Introduction: Prevention effort of progestogen-only prevalence rate injectable discontinuation has not got the national target and it always increases. The prevalence rate is one of causes Total Fertility Rate (TFR) increasing. The study analyzed the risk factors associated with the progestogen-only injectable discontinuation case.

Methods: This study used analytic observational with cross sectional design which was carried out in Puskesmas Mojo Surabaya on March - April 2019. Population are 646 discontinuation acceptors and 5,751 non discontinuation acceptors of progestogen-only injectable. The inclusion criteria were acceptors of progestogen-only injectable discontinuation case, have a husband, not yet menopause. The exclusion criteria were acceptor of progestogen-only injectable discontinuation who used other contraception. Total samples are 44 samples obtained by with consecutive sampling. Independent variables were desire pregnancy, myths, weight change, spotting, amenorrhea, husband support. Dependent variable was the progestogen-only injectable discontinuation case. The data are collected by questionnaire, analyzed by chi-square test with $\alpha<0.005$ and multivariate analysis with independent variable $\mathrm{p}<0.25$
\end{abstract}

Results: The factor which correlated with the progestogen-only injectable discontinuation was husband support $(\mathrm{p}=0.012)$. The factors which not correlated with the case are desire pregnancy $(p=1.000)$, myths $(p=0.138)$, weight change $(p=0.378)$, spotting $(p=0.164)$, amenorrhea $(\mathrm{p}=0.192)$. The dominant factor was husband support (Odds Ratio $=26.571$; $95 \% \mathrm{Cl}=2.497-282.736)$.

Conclusion: The dominant factor in this study is husband support.

Laila, N., Budiono., Sunarsih., \& Aditiawarman. (2019). Faktor Risiko Dropout Kontrasepsi Suntik Progesteron. Pediomaternal Nurs. J., 5(2), 166-174.

\section{PENDAHULUAN}

Upaya penanggulangan angka dropout kontrasepsi suntik progesteron tidak mencapai target dan selalu mengalami peningkatan yaitu dari 25\% tahun 2012 menjadi 27,8\% tahun 2017 (1). Kasus ini juga terjadi di Surabaya yaitu 9.920 kasus pada tahun 2015, 33.984 kasus pada tahun 2016. Puskesmas Mojo Surabaya juga mengalami peningkatan yaitu tahun 2015 sebesar 136 kasus, tahun 2016 sebesar 157 kasus, tahun 2017 sebesar 353 kasus (2).

Dropout kontrasepsi suntik progesteron merupakan salah satu penyebab peningkatan Total
Fertility Rate (TFR) yaitu dari 2,28 tahun 2016 menjadi 2,4 tahun 2017 (3) dan ini tidak mencapai target internasional yaitu 2,1 (4). TFR yang tinggi dapat menyebabkan laju pertumbuhan penduduk meningkat. Hal ini dapat mengakibatkan masalah kependudukan juga semakin meningkat diantaranya jumlah penduduk tinggi, penyebaran penduduk tidak merata, dominasi struktur umur muda, dan rendahnya kualitas penduduk sehingga kemajuan suatu bangsa menjadi terhambat (5). Padahal kontrasepsi suntik progesteron termasuk kontrasepsi dengan efektifitas tinggi. Jika dipakai secara teratur dan sesuai jadwal, angka kegagalan 
dari kontrasepsi suntik progesteron adalah 0,3 kehamilan dari 100 wanita (6). Jika jumlah dropout kontrasepsi suntik progesteron semakin meningkat maka jumlah kehamilan yang tidak diinginkan akan meningkat. Begitu pula dengan TFR.

Faktor yang dapat menyebabkan dropout kontrasepsi suntik progesteron antara lain keinginan hamil $(31,6 \%)$, terpengaruh mitos (50\%), mengalami efek samping $(40,7 \%)$ seperti kenaikan berat badan $(18,6 \%)$, spotting $(7,8 \%)$, amenorea $(48,1 \%)$, tidak adanya dukungan suami $(0,2 \%)(7-13)$.

Konseling, Informasi, dan Edukasi (KIE) yang adekuat tentang kontrasepsi suntik 3 bulan berupa cara kerja dan kemungkinan efek samping yang terjadi penting dilakukan bidan dengan tujuan dapat dilakukan manajemen yang tepat ketika hal tersebut muncul. KIE juga diberikan pada suami dan keluarga agar penggunaan metode ini lebih diterima karena kebanyakan KIE hanya diberikan pada ibu (8). Mitos dan stigma pada masyarakat dapat diluruskan dengan cara lebih banyak mengadakan diskusi tentang efek samping dengan menggunakan bahasa sederhana (14). Penelitian ini bertujuan untuk menganalisis faktor yang berhubungan dengan kejadian dropout pada kontrasepsi suntik 3 bulan.

\section{METODE}

\subsection{Desain}

Penelitian ini menggunakan analitik observasional dengan pendekatan cross sectional.

\subsection{Populasi, sampel, dan sampling}

Populasi yang digunakan yaitu seluruh akseptor murni kejadian dropout kontrasepsi suntik progesteron 2015-2017 di Puskesmas Mojo Surabaya. Sampel yang digunakan sebesar 44 sampel dengan 25 sampel dropout dan 19 sampel non dropout kontrasepsi suntik progesteron. Teknik pengambilan sampel menggunakan consecutive sampling yaitu pengambilan sampel sesuai dengan kriteria yang ditetapkan. Lokasi penelitian di Puskesmas Mojo Surabaya. Pengambilan data dilaksanakan pada bulan Maret - April 2019.

\subsection{Variabel}

Variabel independen adalah keinginan hamil, mitos, perubahan berat badan, spoting, amenorea, dukungan suami. Variabel dependen adalah kejadian dropout kontrasepsi suntik progesteron.

\subsection{Instrumen}

Instrumen penelitian ini menggunakan kuisioner dengan 26 pertanyaan yaitu 6 pertanyaan karakteristik responden (nama, usia, paritas, agama, pendidikan, pekerjaan), 1 pertanyaan kejadian dropout kontrasepsi suntik progesteron, 1 pertanyaan keinginan hamil, 4 pertanyaan mitos (mitos, jenis, sumber, waktu mendengar mitos), 4 pertanyaan perubahan berat badan (perubahan BB, BB sebelum, BB sesudah, perubahan BB mengganggu), 5 pertanyaan spotting (spotting, waktu terjadi, anggapan spotting sebagai menstruasi, larangan spotting, spotting mengganggu), 2 pertanyaan amenorea (amenorea, amenorea mengganggu), 3 pertanyaan dukungan suami (dukungan suami, alasan mendukung, alasan tidak mendukung)

\subsection{Prosedur}

Peneliti mengajukan surat permohonan perizinan penelitian ke Program Studi S1 Kebidanan dan layak etik Fakultas Kedokteran Universitas Airlangga, Bakesbangpol Surabaya (Badan Kesatuan Bangsa, Politik, dan Perlindungan Masyarakat) serta Dinas Kesehatan Kota Surabaya. Setelah itu, peneliti melakukan pengambilan data di Puskesmas Mojo Surabaya dengan wawancara menggunakan kuisioner penelitian dan menjelaskan tujuan penelitian serta memberikan lembar persetujuan menjadi responden untuk ditandatangani. Kuisioner yang telah diisi dianalisis lebih lanjut.

Tabel 1. Karakteristik Responden di Puskesmas Mojo Surabaya (N=44)

\begin{tabular}{|c|c|c|c|}
\hline Kategori & & Frekuensi (n) & Presentase (\%) \\
\hline \multirow[t]{3}{*}{ Umur } & $<20$ tahun & 1 & 2,3 \\
\hline & 20-35 tahun & 19 & 43,2 \\
\hline & $>35$ tahun & 24 & 54,5 \\
\hline \multirow[t]{2}{*}{ Paritas } & Primipara & 11 & 25 \\
\hline & Multipara & 33 & 75 \\
\hline \multirow[t]{2}{*}{ Pekerjaan } & Bekerja & 15 & 34,1 \\
\hline & Tidak Bekerja & 29 & 65,9 \\
\hline \multirow[t]{6}{*}{ Agama } & Islam & 44 & 100 \\
\hline & Katolik & 0 & 0 \\
\hline & Kristen Protestan & 0 & 0 \\
\hline & Hindu & 0 & 0 \\
\hline & Budha & 0 & 0 \\
\hline & Konghuchu & 0 & 0 \\
\hline \multirow[t]{3}{*}{ Pendidikan } & Dasar & 8 & 18,2 \\
\hline & Menengah & 31 & 70,5 \\
\hline & Tinggi & 5 & 11,4 \\
\hline
\end{tabular}




\subsection{Analisis}

Analisis data yang digunakan adalah analisi univariat (distribusi frekuensi), analisis bivariat (uji Chi Square dengan $\alpha<0,005$ ), analisis multivariat (uji Regresi Logistik Berganda dengan variabel independen $\mathrm{p}<$ 0,25 ).

\subsection{Ethical Clearance}

Ethical Clereance penelitian ini adalah kelaikan etik Fakultas Kedokteran Universitas Airlangga yaitu 48/EC/KEPK/FKUA/2019. Inform consent dilakukan pada responden dengan hasil penelitian hanya digunakan untuk kepentingan penelitian dan kerahasiaan termasuk identitas tetap terjaga.

\section{Hasil}

Karakteristik umum responden yaitu sebagian besar responden berada pada usia >35 tahun (54,5\%). Sebagian besar responden memiliki lebih dari 1 anak (multipara) (75\%). Responden lebih banyak tidak bekerja $(65,9 \%)$. Responden sebagian besar beragama islam $(100 \%)$ dengan tingkat pendidikan responden yaitu pendidikan menengah (70,5\%) [Tabel 1].

Data penunjang dari setiap faktor menunjukkan bahwa berdasarkan jenis mitos, sebagian besar responden percaya mitos dapat menyebabkan tidak menstruasi $(42,9 \%)$ dan mereka mendengarnya dari teman $(57,1 \%)$ pada saat setelah memakai kontrasepsi suntik progesteron (66,7\%). Berdasarkan efek samping, sebagian besar responden mengalami efek samping (88,6\%). Pertama, perubahan berat badan, sebagian besar responden mengalami BB naik $(72,7 \%)$ dan 52,3\% diantaranya merasa terganggu. Kedua, spotting, sebagian besar responden mengalami spotting di dalam waktu menstruasi $(66,7 \%)$ dan $100 \%$ menganggap spotting sebagai menstruasi dengan larangan beribadah dan berhubungan seksual $(91,7 \%)$, tapi spotting tersebut tidak mengganggu responden (79,5\%). Ketiga, amenorea, sebagian besar amenorea tidak mengganggu responden (59,1\%). Berdasarkan dukungan suami, alasan suami mendukung pemakaian kontrasepsi suntik progesteron karena $56,3 \%$ mendukung apapun keputusan ibu (56,3\%) sedangkan suami tidak mendukung karena tidak menerima efek samping yang dialami istri (50\%) [Tabel 2].

Berikut hasil distribusi frekuensi masing-masing faktor yaitu keinginan hamil diperoleh sebagian besar responden tidak ingin hamil $(68,2 \%)$ dan hanya $32 \%$ responden ingin hamil yang memutuskan dropout. Mitos pun diperoleh sebagian besar tidak ada mitos yang mempengaruhi keputusan responden $(52,3 \%)$ dan hanya $36 \%$ responden yang memutuskan dropout. Perubahan berat badan diperoleh sebagian besar responden mengalami perubahan berat badan (86,4\%) dan 85,7\% memutuskan dropout. Pada spotting diperoleh sebagian besar responden tidak mengalami spotting $(79,5 \%)$ dan hanya $16 \%$ responden spotting yang dropout. Amenorea diperoleh sebagian besar responden dropout mengalami amenorea (56\%), tapi secara keseluruhan responden lebih banyak tidak mengalami amenorea $(54,5 \%)$. Dukungan suami diperoleh sebagian besar suami mendukung pemakaian kontrasepsi suntik progesteron $(72,7 \%)$ dan hanya $44 \%$ dropout karena tidak mendapat dukungan suami.

Berdasarkan analisis chi square, faktor yang berhubungan dengan kejadian dropout kontrasepsi suntik progesteron adalah dukungan suami ( $\mathrm{p}=$ 0,012) dengan OR 14,14. Faktor yang tidak berhubungan dengan kejadian dropout kontrasepsi suntik progesteron adalah keinginan hamil $(\mathrm{p}=$ $1,000)$. Mitos $(p=0,138)$. Perubahan berat badan $(p=$ $0,378)$. spotting $(\mathrm{p}=164)$. amenorea $(\mathrm{p}=0,192)$ [Tabel 3].

Berdasarkan analisis bivariat, dukungan suami didapatkan sebagai faktor yang paling berpengaruh. Dukungan suami menjadi faktor dominan karena memiliki OR tertinggi sebesar 26,571 (95\% Cl=2,497 - 282,736) yang berarti wanita yang tidak mendapat dukungan suami dalam pemakaian kontrasepsi suntik progesteron lebih berisiko 26,571 kali untuk dropout dengan nilai B positif yang berarti jika suami tidak mendukung pemakaian maka angka dropout kontrasepsi suntik progesteron akan meningkat [Tabel 4].

\section{PEMBAHASAN}

\subsection{Hubungan Keinginan Hamil dengan Kejadian Dropout Kontrasepsi Suntik Progesteron}

Keinginan hamil tidak berhubungan dengan kejadian dropout kontrasepsi suntik progesteron $(\mathrm{p}=1,000)$. Penelitian ini tidak sejalan dengan penelitian Khan (2015) (12) di Uttar Pradesh dan Rajasthan, India dengan hasil keinginan hamil berhubungan dengan dropout DMPA ( $\mathrm{p}=0,043)$. Penelitian lain yang tidak sejalan yaitu penelitian Maharjan, Tongkumchum and Kakchapati (2016) (11) di Nepal dengan hasil keinginan hamil berhubungan dengan dropout kontrasepsi suntik progesteron ( $p=0,001)$. Tapi penelitian ini sejalan dengan penelitian Hofmeyr (2016) (15) di Afrika Selatan yaitu keinginan hamil tidak berhubungan dengan dropout kontrasepsi IUD dan DMPA $(p=0,41)$.

Keinginan hamil dapat menyebabkan wanita tidak membutuhkan kontrasepsi lagi dan memilih mempersiapkan kehamilan sehingga dropout. Proporsi responden tidak ingin hamil $(68,2 \%)$ lebih besar daripada ingin hamil [Tabel 3]. Artinya, keinginan hamil tidak mempengaruhi seseorang untuk dropout kontrasepsi. Hal ini menyebabkan faktor keinginan hamil tidak signifikan.

Keinginan hamil cenderung terjadi pada pasangan yang menginginkan lebih dari satu anak. Dropout kontrasepsi akan terjadi untuk hamil (16). Berdasarkan [Tabel 1], 75\% responden merupakan multipara sehingga pasangan merasa cukup dengan jumlah anak sekarang dan lebih peduli dengan keadaan keluarga. 
Tabel 2. Data Penunjang Faktor Kejadian Dropout Kontrasepsi Suntik Progesteron (N=44)

\begin{tabular}{|c|c|c|c|}
\hline Kategori & & $\mathbf{n}$ & $\%$ \\
\hline Ada mitos & & 21 & \\
\hline \multirow{7}{*}{ Jenis mitos } & BB naik & 4 & 19 \\
\hline & Perdarahan & 3 & 14,3 \\
\hline & Flek darah & 5 & 23,8 \\
\hline & Tidak menstruasi & 9 & 42,9 \\
\hline & Mandul & 0 & 0 \\
\hline & Kanker & 0 & 0 \\
\hline & Lainnya & 0 & 0 \\
\hline \multirow[t]{5}{*}{ Sumber mitos } & Keluarga & 5 & 23,8 \\
\hline & Tetangga & 3 & 14,3 \\
\hline & Teman & 12 & 57,1 \\
\hline & Internet & 1 & 4,8 \\
\hline & Lainnya & 0 & 0 \\
\hline \multirow[t]{2}{*}{ Waktu mendengar mitos } & Sebelum pakai kontrasepsi suntik progesteron & 7 & 33,3 \\
\hline & Setelah pakai kontrasepsi suntik progesteron & 14 & 66,7 \\
\hline \multirow[t]{2}{*}{ Efek samping } & Mengalami Efek Samping & 39 & 88,6 \\
\hline & Tidak Efek Samping & 5 & 11,4 \\
\hline \multicolumn{4}{|l|}{ Perubahan BB } \\
\hline \multirow[t]{3}{*}{ Status BB } & BB naik & 32 & 72,7 \\
\hline & BB turun & 6 & 13,6 \\
\hline & BB tetap & 6 & 13,6 \\
\hline \multirow[t]{2}{*}{ Perubahan BB mengganggu } & Mengganggu & 23 & 52,3 \\
\hline & Tidak Mengganggu & 21 & 47,7 \\
\hline Mengalami Spotting & & 12 & \\
\hline \multirow[t]{2}{*}{ Waktu spotting } & Di dalam waktu menstruasi & 8 & 66,7 \\
\hline & Di luar waktu menstruasi & 4 & 33,3 \\
\hline \multirow[t]{2}{*}{ Anggapan spotting sebagai menstruasi } & Menganggap menstruasi & 12 & 100 \\
\hline & Tidak mengganggap menstruasi & 0 & 0 \\
\hline \multirow[t]{3}{*}{ Larangan ketika spotting } & Tidak ada & 1 & 8,3 \\
\hline & Ibadah dan hubungan seksual & 11 & 91,7 \\
\hline & Lainnya & 0 & 0 \\
\hline \multirow[t]{2}{*}{ Spotting mengganggu } & Mengganggu & 9 & 20,5 \\
\hline & Tidak Mengganggu & 35 & 79,5 \\
\hline \multicolumn{4}{|l|}{ Amenorea } \\
\hline \multirow[t]{2}{*}{ Amenorea mengganggu } & Mengganggu & 18 & 40,9 \\
\hline & Tidak Mengganggu & 26 & 59,1 \\
\hline \multicolumn{4}{|l|}{ Dukungan suami } \\
\hline \multirow[t]{4}{*}{ Alasan suami mendukung } & Menganggap kontrasepsi efektif & 3 & 9,4 \\
\hline & Mendukung keputusan apapun ibu & 18 & 56,3 \\
\hline & Cukup dengan jumlah anak sekarang & 8 & 25 \\
\hline & Tidak repot & 3 & 9,4 \\
\hline Total suami mendukung & & 32 & 100 \\
\hline \multirow[t]{4}{*}{ Alasan suami tidak mendukung } & Tidak menerima efek samping & 6 & 50 \\
\hline & Mendengar mitos & 0 & 0 \\
\hline & Ingin mempunyai anak lagi & 5 & 41,7 \\
\hline & Lainnya & 1 & 8,3 \\
\hline Total suami tidak mendukung & & 12 & 100 \\
\hline
\end{tabular}

Pekerjaan akan menyebabkan wanita lebih memilih menggunakan kontrasepsi karena lebih memikirkan pekerjaannya (13). Berdasarkan [Tabel 1], 65,9\% responden tidak bekerja. Pekerjaan dapat dikaitkan dengan status ekonomi keluarga. Jika tidak memiliki pekerjaan harus menunda keinginan hamil karena calon anak selanjutnya akan menambah pengeluaran keluarga.

Sebagian besar responden $(54,5 \%)$ berumur $>35$ tahun sehingga responden dropout bukan karena ingin hamil tapi ada faktor lain yang mempengaruhi [Tabel 1]. Misalnya efek samping, Penelitian Castle
(2015) (13) menunjukkan bahwa 38,1\% wanita memerlukan istirahat dengan menghentikan sementara kontrasepsi karena efek samping dan 6$13 \%$ berhenti karena tidak lagi membutuhkan perlindungan kehamilan. Berdasarkan [Tabel 2], 88\% responden mengalami efek samping dan unmet need dengan pikiran tidak akan hamil lagi karena usia tua dan tidak adanya menstruasi. Survey oleh Ali, Cleland and Shah (2012) (17) di 60 negara menunjukkan bahwa risiko kehamilan bagi unmet need dapat terjadi 6-12 bulan dengan proporsi rata- 
rata $10 \%$ Armenia, Colombia, Dominican Republic Egypt, Ethioplia, Kenya, Malawi, Flipina, Zimbabwe.

Alasan lain adalah ketidakpastian terkait keinginan kehamilan. Jika kehamilan dianggap sebagai suatu keputusan sadar maka akan berubah jika terkait faktor psikologis, lingkungan, sosial, budaya termasuk menganggap suami sebagai kontrol reproduksi (18,19,28-31,20-27). Kesimpulannya, suami merupakan penentu keputusan termasuk kehamilan.

\subsection{Hubungan Mitos dengan Kejadian Dropout} Kontrasepsi Suntik Progesteron

Mitos tidak berhubungan dengan kejadian dropout kontrasepsi suntik progesteron $(\mathrm{p}=0,138)$. reponden mengaku tidak ada mitos (64\%) yang mempengaruhi keputusannya untuk dropout kontrasepsi suntik progesteron. Kemungkinan ada faktor lain yang mempengaruhi.

Hampir di seluruh negara, sifat dari mitos sama yaitu campuran dari pengalaman efek samping dan kabar angin (34). Mitos tidak berdasar dengan pengalaman efek samping kemungkinan memiliki keterkaitan (14). Castle (2015); Khan (2015); Outlook (2015) (12-14) menyebutkan bahwa ada keyakinan kontrasepsi suntik progesteron dapat menyebabkan tidak bisa hamil lagi dan kanker. Wanita percaya bahwa tidak menstruasi menyebabkan darah menumpuk dan berkembang menjadi tumor dalam tubuh (14). Penelitian di

Tabel 3. Analisis Hubungan Faktor dengan Kejadian Dropout Kontrasepsi Suntik Progesteron (N=44)

\begin{tabular}{|c|c|c|c|c|c|c|c|c|c|c|}
\hline \multirow{3}{*}{ Faktor } & \multirow{3}{*}{ Kategori } & \multicolumn{6}{|c|}{$\begin{array}{c}\text { Kejadian Dropout Kontrasepsi Suntik } \\
\text { Progesteron }\end{array}$} & \multirow{3}{*}{$\begin{array}{c}p \\
(\alpha< \\
0,05)\end{array}$} & \multirow{3}{*}{$\begin{array}{l}\text { Odds } \\
\text { Ratio }\end{array}$} & \multirow{3}{*}{$95 \% C I$} \\
\hline & & \multicolumn{2}{|c|}{ Dropout } & \multicolumn{2}{|c|}{ Non dropout } & \multicolumn{2}{|c|}{ Total } & & & \\
\hline & & $\mathbf{n}$ & $\%$ & $\mathbf{n}$ & $\%$ & $\mathbf{n}$ & $\%$ & & & \\
\hline \multirow{2}{*}{$\begin{array}{l}\text { Keinginan } \\
\text { hamil }\end{array}$} & Ingin Hamil & 8 & 32 & 6 & 31,6 & 14 & 31,8 & \multirow{2}{*}{1,000} & \multirow{2}{*}{1,020} & $0,283-$ \\
\hline & Tidak Ingin Hamil & 17 & 68 & 13 & 68,4 & 30 & 68,2 & & & 3,672 \\
\hline \multirow[t]{2}{*}{ Mitos } & Ada Mitos & 9 & 36 & 12 & 63,2 & 21 & 47,7 & \multirow{2}{*}{0,138} & \multirow{2}{*}{0,328} & $0,095-$ \\
\hline & Tidak Ada Mitos & 16 & 64 & 7 & 36,8 & 23 & 52,3 & & & 1,133 \\
\hline \multirow{2}{*}{$\begin{array}{l}\text { Perubahan } \\
\text { berat badan }\end{array}$} & Ada Perubahan BB & 23 & 92 & 15 & 78,9 & 38 & 86,4 & \multirow[b]{2}{*}{0,378} & \multirow[b]{2}{*}{3,067} & \\
\hline & $\begin{array}{l}\text { Tidak Ada } \\
\text { Perubahan BB }\end{array}$ & 2 & 8 & 4 & 21,1 & 6 & 13,6 & & & 18,884 \\
\hline \multirow[t]{2}{*}{ Spotting } & Spotting & 4 & 16 & 7 & 36,8 & 11 & 25 & \multirow{2}{*}{0,164} & \multirow{2}{*}{0,327} & $0,079-$ \\
\hline & Tidak Spotting & 21 & 63,6 & 12 & 63,2 & 33 & 75 & & & 1,349 \\
\hline \multirow[t]{2}{*}{ Amenorea } & Amenorea & 14 & 56 & 6 & 31,6 & 20 & 45,5 & \multirow{2}{*}{0,192} & \multirow{2}{*}{2,758} & $0,791-$ \\
\hline & Tidak Amenorea & 11 & 44 & 13 & 68,4 & 24 & 54,5 & & & 9,613 \\
\hline \multirow[t]{2}{*}{$\begin{array}{l}\text { Dukungan } \\
\text { suami }\end{array}$} & $\begin{array}{l}\text { Tidak Ada Dukungan } \\
\text { Suami }\end{array}$ & 11 & 44 & 1 & 5,3 & 12 & 27,3 & \multirow{2}{*}{0,012} & \multirow{2}{*}{14,143} & \multirow{2}{*}{$\begin{array}{r}1,626- \\
123,001\end{array}$} \\
\hline & $\begin{array}{l}\text { Ada Dukungan } \\
\text { Suami }\end{array}$ & 14 & 56 & 18 & 94,7 & 32 & 72,7 & & & \\
\hline
\end{tabular}

Tabel 4. Tabel Regresi Logistik Berganda Hubungan Variabel Independen dengan Kejadian Dropout Kontrasepsi Suntik Progesteron $(\mathrm{N}=44)$

\begin{tabular}{|c|c|c|c|c|c|}
\hline No & Variabel & B & p value & Odds Ratio & $95 \% \mathrm{Cl}$ \\
\hline 1 & Mitos & $-1,827$ & 0,021 & 0,161 & $0,034-0,763$ \\
\hline 2 & Dukungan suami & 3,280 & 0,007 & 26,571 & $2,497-282,736$ \\
\hline & Constant & 0,479 & 0,318 & 1,614 & \\
\hline
\end{tabular}

Penelitian ini tidak sejalan dengan penelitian Castle (2011) (32)di Mali, Afrika Barat yang menunjukkan mitos mempunyai hubungan positif dengan dropout kontrasepsi karena mitos menyebabkan meningkatkan dropout dini kontrasepsi. Penelitian lain yang sejalan dengan penelitian ini yaitu penelitian Gueye and Org (2015) (33) dengan hasil adanya hubungan negatif antara mitos dengan penggunaan kontrasepsi di Kenya, Afrika Timur yaitu peningkatan kepercayaan terhadap mitos menyebabkan penurunan penggunaan kontrasepsi.

Mitos tentang efek dari kontrasepsi suntik progesteron secara spesifik tersebar luas di masyarakat dan tidak berbasis kompetensi. Mitos yang beredar pun dapat menyebabkan kesalahan persepsi yang mempengaruhi keputusan pengguna kontrasepsi suntik progesteron sehingga dropout $(13,14)$. Berdasarkan [Tabel 3], sebagian besar
Nigeria (Afrika Barat) menemukan bahwa 74,7\% percaya hal tersebut dan tidak akan menggunakan kontrasepsi dengan kemungkinan 0,14 kali untuk infertil dan 0,19 kali untuk kanker. Berdasarkan [Tabel 2], responden tidak pernah mendengar mitos tersebut tapi mendengar kontrasepsi suntik progesteron dapat menyebabkan tidak menstruasi $(42,9 \%)$.

Mitos diperkuat dengan adanya pertukaran informasi di tempat informal (13). Bahkan di Afrika Timur, kesalahpahaman dapat terjadi karena pengguna cenderung mencari wanita lain yang mengalami efek samping yang dijelaskan tenaga kesehatan (14). Berdasarkan [Tabel 2], responden banyak mendengar mitos dari teman $(57,1 \%)$.

Berdasarkan [Tabel 1], sebagian besar responden berusia $>35$ tahun $(54,1 \%)$ dengan tingkat pendidikan menengah (70,5\%). Usia matang dengan 
tingkat pendidikan lebih tinggi menyebabkan pola pikir seseorang lebih cepat memproses informasi dengan mencocokkan pengetahuan yang dimiliki. Jika tidak sesuai atau tidak pernah tahu, mereka memilih memastikan pada bidan atau tenaga kesehatan tentang kebenaran mitos tersebut. Pada akhirnya mereka memilih tidak percaya dan tetap menerima efek samping yang terjadi.

Berbeda dengan penelitian (35) mengenai pengaruh sport massage dan terapi bekam terhadap penurunan kadar asam laktat dan nadi, didapatkan hasil bahwa terapi bekam dapat menurunkan denyut nadi pada mahasiswa putra jurusan pendidikan dan kepelatihan baik pada kelompok kontrol maupun perlakuan. Secara teori banyak faktor yang mempengaruhi frekuensi nadi diantaranya adalah jenis kelamin, umur, posisi tubuh, dan aktivitas fisik (36).

Serupa dengan variabel sebelumnya yaitu intensitas dismenore, setelah pemberian terapi bekam intensitas dismenore mengalami penurunan, sedangkan pada variabel ini penurunan nadi tidak dapat terkaji oleh peneliti, peneliti hanya bisa membandingkan antara kelompok kontrol dan perlakuan sehingga hasil statistik tidak signifikan. Namun, terdapat empat responden dengan pengukuran nadi yang tinggi. Kemungkinan besar, hal tersebut dapat dikarenakan oleh faktor jenis kelamin, aktivitas fisik dan respon autonomik nyeri yang dirasakan oleh responden. Ketika diwawancara, responden mengatakan jika dirinya cenderung tidak tenang ketika mengalami dismenore.

\subsection{Hubungan Perubahan Berat Badan dengan}

Kejadian Dropout Kontrasepsi Suntik Progesteron

Perubahan berat badan tidak berhubungan dengan kejadian dropout kontrasepsi suntik progesteron $(\mathrm{p}=$ 0,378). Penelitian ini hampir sejalan dengan penelitan Gichuhi and Referral (2014) (7) di Kenya, Afrika Timur yang menunjukkan indeks massa tubuh akhir tidak berhubungan dengan dropout DMPA dan IUD dalam 12 bulan pemakaian $(\mathrm{p}=0,7250)$. Penelitian ini tidak sejalan dengan penelitian Beksinska et al. (2010) (37) di Afrika Selatan yang menemukan kenaikan berat badan berhubungan dengan dropout kontrasepsi suntik dan kontrasepsi lain pada $4-5$ tahun pemakaian $(\mathrm{p}=0,02)$. Penelitian Veisi and Zangeneh (2013) (10) di Iran juga tidak sejalan yaitu kenaikan berat badan berhubungan dengan dropout kontrasepsi suntik ( $\mathrm{p}=0,038)$ karena kenaikan berat badan menjadi fokus utama perempuan yaitu $48 \%$ berat badan meningkat setelah 6 bulan pemakaian.

Perubahan berat badan dengan kenaikan berat badan dapat terjadi secara lambat bahkan dapat secara cepat. Normalnya, pada tahun pertama pemakaian kontrasepsi suntik progesteron akan terjadi kenaikan berat badan sekitar 0,5-2,0 kg dan 10-12 kg setelah pemakaian 4-6 tahun (38). Wanita menganggap kenaikan berat badan sangat mengganggu dan tidak dapat menerima keadaan tubuhnya sehingga dropout $(8,39)$.
Berdasarkan [Tabel 2], proporsi perubahan berat badan antara dropout (92\%) dan non-dropout $(78,9 \%)$ hampir seimbang. Rata-rata responden juga mengalami berat badan naik $(72,7 \%)$. Perasaan terganggu $(52,3 \%)$ dengan tidak terganggu $(47,7 \%)$ terhadap perubahan berat badan juga hampir seimbang. Artinya, selain responden dropout karena perubahan berat badan namun sebagian responden lebih menerima efek samping tersebut dan tidak dropout. Hal ini menyebabkan faktor perubahan berat badan tidak signifikan..

Menurut Qonitun (2017) (40), efek samping pada wanita pengguna kontrasepsi suntik progesteron tergantung sistem hormon setiap individu. Kandungan hormon progesteron menyebabkan nafsu makan meningkat sehingga porsi dan frekuensi makan juga berpengaruh dalam perubahan berat badan (41). Perubahan berat badan cenderung terjadi lebih cepat jika porsi dan makan meningkat atau menurun. Namun hal ini tidak didesain dalam penelitian ini.

\subsection{Hubungan Spotting dengan Kejadian Dropout Kontrasepsi suntik progesteron}

Spotting tidak berhubungan dengan kejadian dropout kontrasepsi suntik progesteron (p 0,164). Penelitian ini tidak sejalan dengan penelitian Zigler and McNicholas (2017) (42) di Amerika yaitu spotting kemungkinan berhubungan dengan dropout kontrasepsi suntik progesteron walaupun tingkat penggunaan dan kepuasannya tinggi.

Penelitian ini sejalan dengan penelitian Veisi and Zangeneh (2013) (10) di Iran yaitu perubahan pola menstruasi tidak berhubungan dengan dropout DMPA dan IUD ( $p=0,307)$. Penelitian lain di Nigeria, Afrika Barat oleh Liu, Shen and Diamond-Smith (2018) (43) menunjukkan bahwa spotting tidak berhubungan dengan keputusan melanjutkan pemakaian kontrasepsi suntik progesteron.

Spotting yang terjadi pada akseptor kontrasepsi suntik progesteron menyebabkan ketidakpuasan dengan pola perdarahan yang terjadi yaitu tidak teratur dan tidak terjadwal sehingga mengganggu dan dropout (44). Proporsi responden spotting lebih banyak tidak dropout (36,8\%) daripada dropout (16\%) kontrasepsi suntik progesteron. 73,7\% responden non dropout juga mengaku merasa terganggu dengan spotting [Tabel 2]. Artinya, sebagian besar responden lebih menerima efek samping spotting yang dialami. Hal ini merupakan penyebab faktor spotting tidak signifikan.

Proporsi responden tidak spotting $(73,7 \%)$ juga lebih banyak dropout. Kemungkinan karena responden lebih banyak mengalami amenorea $(54,4 \%)$ [Tabel 3]. Penelitian serupa oleh Shafaie (2014) (9) di Iran menunjukkan bahwa 54,5\% penyebab terbanyak dropout kontrasepsi suntik progesteron adalah amenorea. Penelitian lain di Nigeria, Afrika Barat juga menunjukkan amenorea merupakan alasan terbanyak wanita dropout kontrasepsi suntik progesteron (8). 
Berdasarkan [Tabel 2], semua responden menganggap spotting sebagai menstruasi (100\%). 91,7\% dilarang beribadah dan berhubungan seksual karena semua reponden beragama islam (100\%). $66,7 \%$ responden menyatakan spotting terjadi dalam waktu menstruasi. Artinya, walaupun responden merasa terganggu dengan spotting yang dialami namun mereka telah terbiasa menghindari larangan menstruasi. Namun, semakin lama spotting, wanita akan semakin bingung dan terganggu karena harus menghindari larangan menstruasi lebih lama.

\subsection{Hubungan Amenorea dengan Kejadian Dropout Kontrasepsi suntik progesteron}

Amenorea tidak berhubungan dengan kejadian dropout kontrasepsi suntik progesteron ( $\mathrm{p}=0,192)$. Penelitian ini tidak sejalan dengan penelitian Hofmeyr et al. (2016) (15) di Afrika Selatan yaitu amenorea berhubungan dengan dropout kontrasepsi suntik progesteron dan IUD (p 0,004).

Akseptor yang mengalami amenorea dapat merasa terganggu karena perubahan pola menstruasi dan jika tidak dapat beradaptasi akan dropout karena hilangnya kebiasaan menstruasi teratur setiap bulan $(8,13,45)$.

Berdasarkan [Tabel 3], sebagaian besar responden amenorea $(68,4 \%)$ memutuskan tidak dropout. Selain itu, sebagian besar responden juga merasa tidak terganggu dengan amenorea (59,1\%). Artinya, responden lebih memilih menerima efek samping tersebut. Hal ini yang menyebabkan faktor amenorea tidak signifikan.

\subsection{Hubungan Dukungan Suami dengan Kejadian Dropout Kontrasepsi suntik progesteron}

Dukungan suami berhubungan dengan kejadian dropout kontrasepsi suntik progesteron ( $\mathrm{p}=0,012$ ). Penelitian ini sejalan dengan penelitian Prasetyo (2015) (46) di Semarang, Jawa Tengah, Indonesia yaitu dukungan suami berhubungan dengan dropout kontrasepsi ( $\mathrm{p}=0,000)$. Penelitian lain oleh MacLachlan (2018) (47) juga menemukan dukungan suami berhubungan dengan dropout kontrasepsi suntik progesteron di dua tempat yaitu Burkina Faso, Afrika Barat ( $\mathrm{p}=<0,001$ ) dan Uganda, Afrika Timur ( $\mathrm{p}$ = 0,04). Penelitian Cover (2018) (49) di Uganda, Afrika Timur juga didapatkan hasil dukungan suami berhubungan dengan dropout kontrasepsi suntik yang dilakukan sendiri dan di tenaga kesehatan $(\mathrm{p}=$ 0,00).

Suami biasanya akan berpengaruh dan bertanggung jawab penuh dalam pengambilan keputusan di suatu keluarga termasuk kontrasepsi (50). Jika suami mendukung pemakaian kontrasepsi suntik progesteron maka akan memberikan ketenangan pada istri sehingga pemakaian pun menjadi konsisten. Sebaliknya jika suami tidak mendukung, dropout kontrasepsi akan meningkat.

Alasan terbanyak suami tidak mendukung pemakaian kontrasepsi suntik progesteron karena khawatir terhadap efek samping yang dialami istri. Suami bertanggung jawab dan menginginkan pasangannya sehat $(12,13,51)$. Berdasarkan [Tabel 2], alasan suami tidak mendukung karena karena khawatir efek samping yang dialami istri (50\%).

\subsection{Faktor Dominan Kejadian Dropout Kontrasepsi suntik progesteron}

Faktor paling berpengaruh dalam kejadian dropout kontrasepsi suntik progesteron adalah dukungan suami dan mitos yaitu anita yang tidak mendapat dukungan suami dalam pemakaian kontrasepsi suntik progesteron lebih berisiko 26,571 kali untuk dropout sedangkan mitos memiliki pengaruh kecil.

Penelitian ini hampir sama dengan penelitian MacLachlan (2018) (47) di Burkina Faso, Afrika Barat dan Uganda, Afrika Timur yaitu dukungan suami merupakan faktor berpengaruh kedua setelah umur dengan OR 0,48 (95\%Cl=0,34-0,6). Penelitian Cover (2018) (48) juga menunjukkan dukungan suami merupakan faktor berpengaruh keenam dengan OR $0,70(95 \% \mathrm{Cl}=0,55-0,89)$

Risiko dropout akan berkurang jika ada dukungan suami dalam pemakaian kontrasepsi suntik progesteron. Berdasarkan Tabel 4, nilai B positif dengan arti risiko dropout akan berkurang jika ada dukungan suami karena $94,7 \%$ responden non dropout mendapat dukungan suami dan hanya $44 \%$ suami tidak mendukung pemakaian kontrasepsi suntik progesteron karena efek samping yang dialami istri (50\%) [Tabel 3].

\section{KESIMPULAN}

Faktor yang berhubungan dengan kejadian dropout kontrasepsi suntik progesteron adalah dukungan suami. Faktor yang tidak berhubungan adalah keinginan hamil, mitos, perubahan berat badan, spotting, amenorea. Faktor yang paling berpengaruh pada penelitian ini adalah dukungan suami. Suami perlu diikutsertakan dalam pemberian KIE dan persetujuan penggunaan kontrasepsi untuk meningkatkan partisipasi dalam kontrasepsi sehingga dapat membantu mengambil keputusan kontrasepsi yang membutuhkan kedua belah pihak.

\section{UCAPAN TERIMA KASIH}

Peneliti mengucapkan terima kasih sebesar-besarnya kepada, Tim pengajar dan jajaran sekretariat Program Studi Kebidanan Fakultas Kedokteran Universitas Airlangga yang telah memberikan arahan dan memfasilitasi dalam menyelesaikan skripsi, Puskesmas Mojo Surabaya yang telah memberikan izin dan bimbingan selama proses pengumpulan data dan ibu akseptor dropout kontrasepsi suntik progesteron di wilayah Puskesmas Mojo Surabaya yang telah meluangkan waktunya dan bersedia menjadi responden penelitian ini.

\section{DAFTAR PUSTAKA}

1. Riskesdas (Riset Kesehatan Dasar). Riset Kesehatan Dasar. Jakarta; 2013. 
2. Dinas Kesehatan Surabaya. Jumlah Dropout Peserta KB Suntik 3 Bulan di Puskesmas Kota Surabaya Tahun 2013-2017. Surabaya; 2018.

3. BKKBN. Laporan Akuntabilitas Kinerja Instansi Pemerintah 2017. Priohutomo S, editor. Jakarta: Badan Kependudukan dan Keluarga Berencana Nasional; 2017.

4. Population Reference Bureau. World Population Data Sheet. 2015 World Population Data Sheet. 2015. 23 p.

5. BKKBN. Laporan Akuntabilitas Kinerja Instansi Pemerintah 2015. 2015. 95 p.

6. Affandi B. Buku Panduan Praktis Pelayanan Kontrasepsi. Jakarta: Bina Pustaka Sarwono Prawirohardjo; 2014.

7. Gichuhi JW, Referral M. The Effect Of Depot Medroxyprogesterone Acetate Contraceptive On Body Weight And Blood Pressure In Indigenous Kenyan Women. Eur Int J Sci Techn ology. 2014;3(6):37-46.

8. Njoku CO, Emechebe CI, Iklaki CU, Njoku AN, Ukaga JT. Progestogen-Only Injectable Contraceptives: The Profile of the Acceptors, Side Effects and Discontinuation in a Low Resource Setting, Nigeria. Open J Obstet Gynecol. 2016;06(04):189-95.

9. Shafaie FS, Homayounfar N, Malaquti J, Amani F. Compare of continuation rate and reasons for discontinuation of DMPA contraceptive among Iranian women referred to Tabriz and Ardebil health centers. Int J Women's Heal Reprod Sci. 2014;2(4):240-4.

10. Veisi F, Zangeneh M. Comparison of Two Different Injectable Contraceptive Methods: Depo-medroxy Progesterone Acetate (DMPA) and Cyclofem. J Fam Reprod Heal. 2013;7(3):109-13.

11. Maharjan M, Tongkumchum $\mathrm{P}$, Kakchapati S. Social determinants of discontinuation of depoprovera among married women in Nepal. Edorium J Public Heal. 2016;6(August):1-3.

12. Khan ME, Dixit A, Ahmad J, Pillai G. Introduction Of DMPA in Public Health Facilities of Uttar Pradesh and Rajasthan: An Evaluation. New Delhi, India: The Population Council; 2015.

13. Castle S, Askew I, Harcourt J, Dasgupta A, Longfield K. Contraceptive Discontinuation: Reasons, Challenges, and Solutions. Family Planning 2020 Population Council. London: Family Planning 2020, Population Council; 2015. 6-10 p.

14. Outlook. Countering Myths and Misperceptions about Contraceptives. June 2015. Outlook on Reproductive Health. USA: Path; 2015.

15. Hofmeyr GJ, Singata-Madliki M, Lawrie TA,
Bergel E, Temmerman M. Effects of the copper intrauterine device versus injectable progestin contraception on pregnancy rates and method discontinuation among women attending termination of pregnancy services in South Africa: A pragmatic randomized controlled trial. Reprod Health. 2016;13(1):1-8.

16. Mufdlilah M, Aryekti K. Factors Causing Contraceptive Acceptors Drop Out. Kesmas Natl Public Heal J. 2018;12(4):202.

17. Ali MM, Cleland J, Shah IH. Causes and consequences of contraceptive discontinuation. World Health Organization. Egypt: World Health Organization; 2012.

18. Santelli J, Lindberg LD, Orr MG, Finer LB, Speizer I. Toward A Multimedimensional Measure of Pregnancy Intentionts: Evidence from The United States. Stud Fam Plann. 2009;40(87100).

19. Lacovou M, Tavares LP. Yearning, Learning, And Conceding: Reasons Men And Women Change Their Childbearing Intentions. Popul Dev Rev. 2011;37(89-123).

20. Joyce T, Kaestner R, Korenman S. The Stability Of Pregnancy Intentions And Pregnancy-Related Maternal Behaviors. Matern Child Heal J. 2000;4(171-8).

21. Sheffler KM, Greil AL, Mitchell KS, McQuillan J. Variation In Pregnancy Intendedness Across U.S. Women's Pregnancies. Matern Child Heal J. 2015;19(932-8).

22. Luker KC. A Reminder That Human Behavior Frequently Refuses To Conform To Models Created By Researchers. Farm Plann Perspect. 1999;31(248-9).

23. Morgan SP, Rackin H. The Correspondence Between Fertility Intentions And Behavior In The United States. Popul Dev Rev. 2010;36(91118).

24. Schoen R, Astone NM, Kim YJ, Nathanson CA, Fields JM. Do Fertility Intentions Affect Fertility Behavior? J Marriage Farm. 1999;61(790-9).

25. Messer LC, Dole N, Kaufman JS, Savitz DA. Pregnancy Intendedness, Maternal Psychosocial Factors and Preterm Birth. Matern Child Heal J. 2005;9(403-12).

26. Klerma LV. The Intendedness of Pregnancy: A Concept in Transition. Matern Child Heal J. 2000;20(155-62).

27. Cha S, Chapman DA, Wan W, Burton CW, Macho SW. Discordant Pregnancy Intentions In Couples And Rapid Repeat Pregnancy. Am J Obs Gynecol. 2016;214(494):1-12.

28. Borrero S, Nikolajski C, Steinberg JR, Freedman L, Akers AY, Ibrahim S. "'It just happens"': a 
qualitative study exploring low-income women's perspectives on pregnancy intention and planning. Contraception. 2015;91(150-6).

29. Higgins JA, Popkin RA, Santelli JS. Pregnancy Ambivalence And Contraceptive Use Among Young Adults In The United States. Perspect Sex Reprod Heal. 2012;44(2):36-43.

30. Kagesten A, Bajos N, Bohet A, Moreau C. Male Experiences of Unintended Pregnancy: Characteristics And Prevalence. Hum Reprod. 2015;30(186-96).

31. Mumford SL, Ph D, Sapra KJ, Ph D, King RB, Ph D, et al. Pregnancy intentions - a complex construct and call for new measures. Fertil Steril. 2016;(34).

32. Sarah Castle. Women's Social Networks, Family Planning Use and Unmet Need: Formative Research Findings from Terikunda Jékulu. United State: USAID; 2011.

33. Gueye A, Org A. Belief in Family Planning Myths at the Individual And Community Levels and Modern Contraceptive Use in Urban Africa HHS Public Access. Int Perspect Sex Reprod Heal. 2015;41(4):191-9.

34. Diamond-Smith N., Campbell M., S. Madan. Misinformation and Fear of Side Effects of Family Plan- ning. Cult Heal Sex. 2012;14(4):421-33.

35. Ningsih Y. Hubungan Intensitas Nyeri Akut dengan Tekanan Darah Pada Pasien di Rumah Sakit Umum Daerah Temanggung. J Phys Educ Heal Sport. 2016;3(2):135-43.

36. McArdle W, Katch F, Katch V. Exercise Physiology: Nutrition, Energy, and Human Performance. 2010.

37. Beksinska ME, Smit JA, Kleinschmidt I, Milford C, Farley TMM. Prospective study of weight change in new adolescent users of DMPA, NET-EN, COCs, nonusers and discontinuers of hormonal contraception. Contraception. 2010;81(1):30-4.

38. Medforth J. Kebidanan Oxford: dari Bidan untuk Bidan. Praptiani W, editor. Jakarta: EGC; 2011. 524-526 p.

39. Lopez LM, Edelman A, Chen-Mok M, Trussell J, Helmerhorst frans $M$. Progestin-only contraceptives: Effects on Weight (Review) Summary of Findings for The Main Comparison. Group CFR, editor. The Cochrane Collaboration. USA: John Wiley \& Sons, Ltd.; 2013.

40. Qonitun U. Hubungan Antara Efek Samping Kontrasepsi Dmpa Dengan Kejadian Drop Out Pada Pasangan Usia Subur (Pus) Di Desa Mandirejo Kecamatan Merakurak Kabupaten Tuban. J Midpro. 2017;9(2):30-4.

41. Mirah DA. Perbedaan Perubahan Berat Badan
Pengguna Kontrasepsi Suntik DMPA dan Kombinasi (DMPA dan Estrogen) Berdasarkan Lama Penggunaan di BPM Farida Hajri Surabaya. Universitas Airlangga; 2017.

42. Zigler RE, McNicholas C. Unscheduled vaginal bleeding with progestin-only contraceptive use. Am J Obstet Gynecol. 2017;216(5):443-50.

43. Liu J, Shen J, Diamond-Smith N. Predictors of DMPA-SC continuation among urban Nigerian women: the influence of counseling quality and side effects. Contraception. 2018;

44. Raidoo S, Kaneshiro B. Unscheduled Bleeding on Hormonal Contraceptives: Pathophysiology, Evaluation, and Management Options. Curr Obstet Gynecol Rep. 2017;6(2):118-25.

45. Tolley EE, Mckenna K, Mackenzie C, Ngabo F, Munyambanza E. Preferences for A Potential Longer-Acting Injectable Contraceptive: Perspectives From Women, Providers, and Policy Makers in Kenya and Rwanda. Glob Heal Sci Pract. 2014;2(2):182-94.

46. Prasetyo SE. Analisis Faktor yang Berhubungan dengan Kejadian Drop Out Akseptor KB Kecamatan GunungPati Kota Semarang. Vol. April 2015, Jurnal Ilmu Kesehatan Masyarakat Fakultas Ilmu Keolahragaan Universitas Negeri Semarang. Universitas Negeri Semarang; 2015.

47. MacLachlan E, Atuyambe LM, Millogo T, Guiella G, Yaro S, Kasasa S, et al. Continuation of subcutaneous or intramuscular injectable contraception when administered by facilitybased and community health workers: findings from a prospective cohort study in Burkina Faso and Uganda. Contraception. 2018;98(5):423-9.

48. Cover J, Namagembe A, Tumusiime J, Nsangi D, Lim J, Nakiganda-Busiku D. Continuation of injectable contraception when self-injected vs. administered by a facility-based health worker: a nonrandomized, prospective cohort study in Uganda. Contraception. 2018;98(5):383-8.

49. Chirenje ZM, Dhibi N, Handsfield HH, Gonese E, Tippett Barr B, Gwanzura L, et al. The Etiology of Vaginal Discharge Syndrome in Zimbabwe: Results from the Zimbabwe STI Etiology Study. Sex Transm Dis Assoc. 2018;45(6):422-8.

50. Yuliani NA. Faktor-Faktor yang Berhubungan dengan Keikutsertaan Wanita Pasangan Usia Subur (PUS) dalam Menggunakan Kontrasepsi Intra uterine Device (IUD) di Wilayah Kerja Puskesmas Mojo Surabaya. Universitas Airlangga; 2018.

51. Mufdlilah, Aryekti K. Dukungan suami terhadap kejadian Drop Out Akseptor Keluarga Berencana (KB) di desa dan kota di Daerah Istimewa Yogyakarta. Musawa. 2016;15(1):103-13. 